\title{
Review on Super Capacitor-Battery based Hybrid Energy Storage System for PV Application
}

\author{
Astha Shrivastava ${ }^{1}$, Sujata Gupta ${ }^{2}$ \\ ${ }^{1}$ M.Tech Scholar, IES IPS ACADEMY Indore, India \\ ${ }^{2}$ Associate professor, IES IPS ACADEMY, Indore, India
}

\begin{abstract}
Hybrid energy storage systems are becoming an option for energy management in better performance of automotive, hybrid electrical vehicle and avionics systems. The main objective of this paper is to review and study of Hybrid Energy Storage System for PV application and to increase energy efficiency, behavior of super capacitor and utility scale storage facilities using renewable and non-renewable energy sources. Literature survey clear problem has been observed from single energy storage system (ESS) aspects and solution of hybrid energy storage system. Therefore review about Battery-super capacitor Hybrid Energy Storage System to high energy density, high power density as well as to improve battery lifetime extension and power enhancement. This paper is based on study and review of Hybrid Energy Storage System using Super capacitor, Battery and PV Module for any Load.
\end{abstract}

Keywords- Hybrid Energy Storage system, Super capacitor, $P V$.

\section{INTRODUCTION}

The main disadvantages of renewable energy sources are that they are much expensive, intermittent, reliability of supply reliability and to generate qualities of electricity. The amount of solar energy reaching the earth's surface is 6000 times the amount of energy used by all human beings worldwide. An HESS is characterized by a beneficial coupling of two or more energy storage technologies with energy and power density, self-discharge rate, efficiency, life-time operating characteristics. The energy storage industry has just begun exploring hybrid solutions for gridscale, called Hybrid Energy Storage Systems (HESS) it combines two or more energy storage technologies with complementary characteristics to provide optimal solution not achievable by any one technology. The hybrid energy storage system (HESS) concept is gaining importance in applications requiring load leveling, high-density energy storage, and emergency power [1]. Batteries are one of most cost-effective energy storage technologies [1][2][3][4]. They are widely used in portable electronics, hybrid or electric vehicles, and even in utility power systems [2]. Li-ion battery is widely used in applications to its high energy density, proven safety, and competitive cost. Super capacitor-Battery based hybrid energy storage systems for PV Application shown that the HESS is able to satisfy output power requirements, while allocating the ripple current and the fast power fluctuations to the super capacitor while maintaining operation of the super capacitor within predefined voltage limits. Super-capacitor with long lifecycle and high energy efficiency is evaluated in automotive industry and academia for hybrid energy storage system [11].

As the cost is continuously decreasing, photovoltaic (PV) generation has become one of the most important renewable energy sources and is being widely used. Gridconnected solar photovoltaic power plants are being installed globally at a fast pace [3]. Pumped hydro and hydrogen storage have been applied for utility-scale storage facilities and large [4].Power Electronics function to establish quantitatively mathematical relationship between the battery/SC parameters and HEV demanded power [10]

\section{OBJECTIVE OF REVIEW}

The main objective of review is to presents a technique for Hybrid Energy Storage System for PV system and to increase the energy efficiency by using renewable energy sources. The goals of this work are to design a Supercapacitor-Battery based hybrid energy storage system for PV Application. This document begins with a technical review of relevant technologies for single energy storage as well multiple energy storage technologies. The hybrid storage systems to be tested and corresponding test scenarios will be presented through MATLAB/Simulink.

In Thilo Bocklisch survey Energy storage coupling architectures, basic energy management concepts and a principle approach for the power flow decomposition based on peak shaving and double low-pass filtering.

In Reza Hemmati et al survey hybridization principles and proposed topologies; power electronics interface architectures, control and energy management strategies, 
and application arenas. Biswajit Ray discusses about pedagogical point of view, modeling and simulation of HESS.

\section{HYBRID ENERGY STORAGE SYSTEM}

The hybrid energy storage system (HESS) concept is gaining importance in applications requiring load leveling, high-density energy storage, and emergency power. Energy sources used in modern HESS in automotive and avionics sectors include high performance batteries such as Li-Ion, super capacitors, and flywheels. HESS provides an excellent platform for system-level modeling and simulation while integrating aspects of electrical power, control systems, and power electronics. Circuit-level models of energy storage devices such as batteries and super capacitors/ultra capacitor can be developed to perform characteristics.

Energy storage Technologies are studied according to below table:

Table.1: Energy Storage Technology

\begin{tabular}{|c|c|c|c|c|c|c|}
\hline $\begin{array}{l}\text { Techn } \\
\text { ology }\end{array}$ & $\begin{array}{l}\text { Pow } \\
\text { er }\end{array}$ & $\begin{array}{l}\text { Ener } \\
\text { gy } \\
\text { Densi } \\
\text { ty }\end{array}$ & $\begin{array}{l}\text { Bac } \\
\text { k- } \\
\text { up } \\
\text { time }\end{array}$ & $\begin{array}{l}\text { Respo } \\
\text { nse } \\
\text { Time }\end{array}$ & $\begin{array}{l}\text { Effeci } \\
\text { ency }\end{array}$ & $\begin{array}{l}\text { Lifet } \\
\text { ime }\end{array}$ \\
\hline $\begin{array}{l}\text { Pumpe } \\
\text { d } \\
\text { Hydro }\end{array}$ & $\begin{array}{l}100 \\
\mathrm{~mW}- \\
2 \mathrm{G} \\
\mathrm{W}\end{array}$ & $\begin{array}{l}400 \mathrm{M} \\
\text { wh- } \\
20 \mathrm{G} \\
\text { wh }\end{array}$ & $\begin{array}{l}\text { Hou } \\
\text { rs }\end{array}$ & $\begin{array}{l}12 \\
\text { Minute } \\
\mathrm{s}\end{array}$ & $\begin{array}{l}70- \\
80 \%\end{array}$ & 50 \\
\hline CAES & $\begin{array}{l}110 \\
\mathrm{~mW}- \\
290 \\
\mathrm{Mw}\end{array}$ & $\begin{array}{l}1.16 \\
\text { Gwh- } \\
3 \mathrm{Gw} \\
\mathrm{h}\end{array}$ & $\begin{array}{l}\text { Hou } \\
\text { rs }\end{array}$ & $\begin{array}{l}12 \\
\text { Minute } \\
\mathrm{s}\end{array}$ & $99 \%$ & $<50$ \\
\hline BESS & $\begin{array}{l}100 \\
\mathrm{~mW}\end{array}$ & $\begin{array}{l}1 \mathrm{kwh} \\
-200 \\
\text { Mwh }\end{array}$ & $\begin{array}{l}\text { Hou } \\
\text { rs }\end{array}$ & $\begin{array}{l}\text { Second } \\
\mathrm{s}\end{array}$ & $\begin{array}{l}60- \\
80 \%\end{array}$ & $<10$ \\
\hline $\begin{array}{l}\text { Flywh } \\
\text { eels }\end{array}$ & $\begin{array}{l}5 \mathrm{~kW} \\
-100 \\
\text { MW }\end{array}$ & $\begin{array}{l}5 \mathrm{Kw} \\
\mathrm{h}-200 \\
\text { Kwh }\end{array}$ & $\begin{array}{l}\text { Min } \\
\text { uts }\end{array}$ & $\begin{array}{l}12 \\
\text { Minute } \\
\mathrm{s}\end{array}$ & $\begin{array}{l}80- \\
95 \%\end{array}$ & 20 \\
\hline $\begin{array}{l}\text { Super } \\
\text { capacit } \\
\text { ors } \\
\end{array}$ & $\begin{array}{l}<1 \mathrm{~m} \\
\mathrm{~W}\end{array}$ & $\begin{array}{l}1 \mathrm{wh}- \\
1 \mathrm{~kW} \\
\mathrm{~h} \\
\end{array}$ & $\begin{array}{l}\text { Seco } \\
\text { nds }\end{array}$ & $\begin{array}{l}\text { Millise } \\
\text { conds }\end{array}$ & $>95 \%$ & $>10$ \\
\hline
\end{tabular}

\section{SUPERCAPACITOR}

Super capacitors are governed by same fundamental equations as conventional capacitors, but utilize higher surface area electrodes and thinner dielectrics to achieve greater capacitances. Electrochemical double-layer capacitors (EDLCs) are constructed from two carbonbased electrodes, an electrolyte, and a separator. In contrast to EDLCs, which store charge electro statically, pseudo capacitors store charge faradaically through the transfer of charge between electrode and electrolyte. Hybrid Capacitors Utilizing both Faradaic and non-
Faradaic processes to store charge. These are a new energy storage technology ideally suited for applications needing repeated bursts of power for fraction of seconds to several minutes. They are capable of packing up to 100 times the energy of conventional capacitors and deliver ten times the power of ordinary batteries. Battery-Super capacitor hybrid energy storage system (HESS) is popular choice for battery lifetime extension, system power enhancement and it can also be used to handle a high frequency power variation which enables the battery lifetime extension as well as reduction in peak power requirement of battery. Battery-Supercapacitor hybrid energy storage system (HESS) gained increased popularity in the energy storage system applications in Grid Energy Storage Systems and Electrical Vehicles. Super capacitors are becoming a promising solution for brake energy storage in rail vehicles.

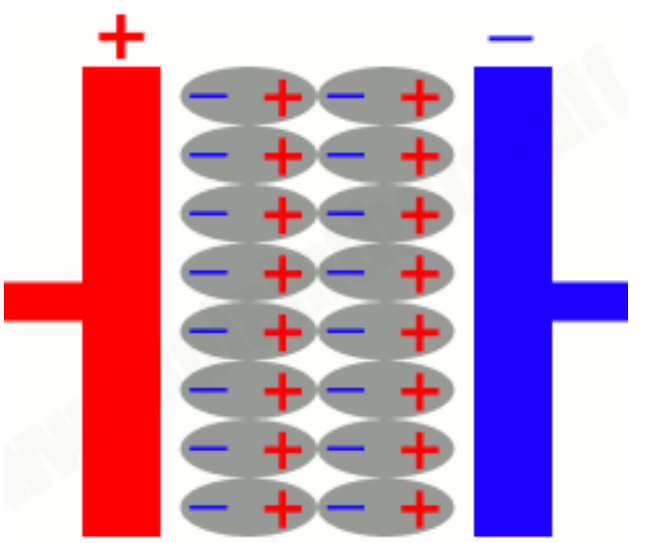

Fig.1: Super capacitor

Table.2: Comparison between Super capacitor and Battery

\begin{tabular}{|c|c|c|c|}
\hline Sr. No. & Characteristics & Battery & $\begin{array}{c}\text { Super } \\
\text { capacitor }\end{array}$ \\
\hline 1. & Charge Time & $\begin{array}{c}10-60 \\
\text { Minutes }\end{array}$ & $1-10$ Seconds \\
\hline 2. & Cycle Life & $\begin{array}{c}500 \& \\
\text { Higher }\end{array}$ & $\begin{array}{c}1 \text { million of } \\
30000 \mathrm{~h}\end{array}$ \\
\hline 3. & $\begin{array}{c}\text { Specific } \\
\text { Power(W/kg) }\end{array}$ & $\begin{array}{c}1000 \text { to } \\
3000\end{array}$ & Upto 10000 \\
\hline 4. & Service Life & 5 to 10 & 10 to 15 years \\
& Years & \\
\hline 5. & $\begin{array}{c}\text { Charge } \\
\text { Temperature('C) }\end{array}$ & 0 to 45 & -40 to 65 \\
\hline
\end{tabular}

\section{SOLAR PHOTOVOLTAIC SYSTEM}

Hybrid Energy Storage System-configuration can be beneficially employed in the context of decentralized PVsystems. HESS are an interesting and very promising flexibility technology, which can help to cover short-, midand longterm fluctuations in a future sustainable, 100\%renewable energy system. Energy storage coupling 
architectures, basic energy management concepts and a principle approach for the power flow decomposition based on peak shaving and double low-pass filtering. Moreover, HESS-configurations, suitable for the application in decentralized PV-systems. Solar photovoltaic system is shown in below figure:

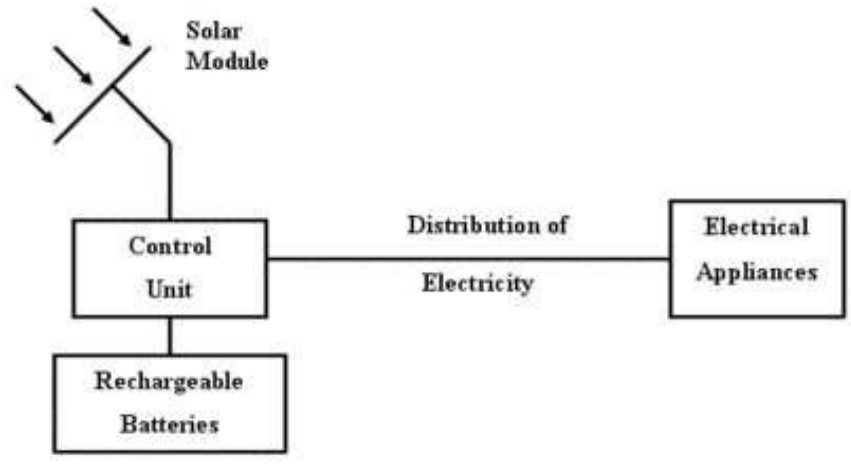

Fig.2: Solar Photovoltaic System

PV plants use silicon solar cells, where Iph is the current of a photo-generated current source, D is a non-linear diode, Rsh and Rs are theinternal parallel and series resistance respectively, $\mathrm{I}_{\mathrm{PV}}$ is the photovoltaic output current, $\mathrm{V}_{\mathrm{PV}}$ is thephotovoltaic output voltage.

$$
I_{p v}=I_{p h}-I_{s}\left(e^{\frac{q\left(V_{p v}+I_{R S}\right)}{A K T_{P V}}}-1\right)-\frac{V_{p v}+I_{p v} R_{s}}{R_{s h}}(\mathrm{I})
$$

Where Isis the diode saturation current, $\mathrm{q}$ is a constant (1.602_10_19C), $\mathrm{k}$ is the Boltzmann constant (1.381 _ $10 \_23 \mathrm{~J}\{\mathrm{~K}), \mathrm{T}_{\mathrm{PV}}$ is absolute temperature when the photovoltaic works, $\mathrm{A}$ is a diode feature fitting coefficient.

\section{CONCLUSION}

As per review of Hybrid energy storage system, super capacitor, Battery and its combinations for any load for application of PV Module. In Hybrid Energy Storage System (HESS) Supercapacitors offer long life, low maintenance, light weight and environmentally friendly solutions when compared to batteries. Behavior of hybrid energy storage systems was study, learned and investigated. It has educational, analysis, experimental behavior and helps for the future work to have a better understanding about designing of Super capacitor-battery based Hybrid Energy Storage System (HESS). Block diagram representation is used to Study about more reliable storage system. Energy storage systems (ESS) are expected to play key roles to improve efficiency and reliability either PV Application or particular load. Hybrid energy storage system (HESS) is an emerging system-level design technique to build a high-performance ESS in a cost-performance way by complementary use of heterogeneous energy storage technologies available. Hybrid energy storage system was studied, designing to perform analysis for different load like linear, non-linear cases which supplied from a battery like lithium ion, lead acid and super capacitor and ultra-capacitor. Energy management of hybrid energy systems is significant against the background of wide application of photovoltaic generation.

\section{REFERENCES}

[1] Y. Zhang et al., "Small-signal modeling and analysis of battery-super capacitor hybrid energy storage systems," IEEE Power and Energy Society. Page1-8, July 2009

[2] K. Yoshimoto, T. Nanahara, G. Koshimizu and Y. Uchida, "New Control Strategy for Regulating Stateof-Charge of a Battery in Hybrid Wind Power/Battery Energy Storage System", IEEE PES, pp. 1244-1251, 2006.

[3] Chang Ye, Shihong Miao *, Qi Lei and Yaowang Li "Dynamic Energy Management of Hybrid Energy Storage Systems with a Hierarchical Structure" MDP Energies 2016.

[4] Florian Klumpp "Potential for large scale energy storage technologies - comparison and ranking including an outlook to 2030" International Renewable Energy Storage Conference, page 124135 IRES 2015

[5] Dmith Buddika Wickramasinghe Abeywardana,et.al "A Fixed Frequency Sliding Mode Controller For A Boost-Inverter-Based Battery Suparcapacitor Hybrid Energy Storage System" IEEE Transaction On Power Electronics, Volume 32, Page 668-680, January 2017.

[6] ThiloBocklisch "Hybrid Energy Storage Systems for Renewable Energy Applications" 9th International Renewable Energy Storage Conference, IRES 2015 Volume 73, Pages 103-111, June 2015.

[7] Reza Hemmati, HedayatSaboori "Emergence of hybrid energy storage systems in renewable energy and transport applications - A review" Renewable and Sustainable Energy Volume 65, Pages 11-23 November 2016.

[8] Biswajit Ray, "Battery/ultra Capacitor Hybrid Energy Storage System for Electric, Hybrid and Plug-in Hybrid Electric Vehicles" IDOSI Publications Page 1122-1126, Year 2014

[9] Biswajit Ray "Designing Hybrid Energy Storage Systems: A Tool for Teaching System-Level Modeling and Simulation" American Society for Engineering Education, 2014.

[10] Cong Zhang, Haitao Min, Yuanbin $\mathrm{Yu}$, QingnianWang,andHuanli Sun "A New Method to Optimize Semiactive Hybrid Energy Storage System for Hybrid Electrical Vehicle by Using PE Function" 
Hindawi Publishing Corporation Volume 2015, pages 14 year 2015 .

[11] M. Masih-Tehrani, M.-R. Hairi-Yazdi, V. Esfahanian, and H. Sagha, "Development of a hybrid energy storage sizing algorithm associated with the evaluation of power management in different driving cycles," Journal of Mechanical Science and Technology, vol. 26, pages 4149-4159, year 2012.

[12] Younghyun Kim , Jason Koh , Qing Xie , Yanzhi Wang , Naehyuck Changb, Massoud Pedram "A scalable and flexible hybrid energy storage system design and implementation" Journal of Power Sources year 2014. 